\title{
Some planting effects still significant after 20 years
}

\author{
R. E. MULLIN
}

Ontario Ministry of Natural Resources

Division of Forests

Forest Research Branch

Midhurst, Ontario

Contribution No. 74-1 of the Ontario Ministry of Natural Resources, Forest Research Branch.

A 1953 planting of unrefrigerated storage of 2-2 red pine contained tests of bales versus crates, and of two planting crews. Storage was to $31 / 2$ weeks with plantings at $1 / 2$ week intervals. Survival and diameter at 20 years have now been examined. Results show a decrease in survival with duration of holding, and an accompanying drop in basal area and volume, in spite of partially compensating increased diameters wtih lower densities. For one week of holding the loss of volume at 20 years was about $12 \%$. Trees from crates survived about $12 \%$ better than those from bales, and achieved about $17 \%$ more volume at 20 years. Differences between planting crews, which did not show up in early survival or height, were significant in the 20th year diameters. One crew obtained about $14 \%$ better basal area and volume at 20 years than the other crew, through better planting.

Quelques effets encore existants après 20 ans de plantation. Il s'agit d'une plantation effectuée en 1953 au moyen de semis 2-2 de pin rouge. Le matériel avait été conservé un certain temps, non réfrigéré, et de 2 façons: en ballots et dans des cageots (caisses de bois). Cette plantation était installée par 2 équipes. La durée de l'entreposage dura $31 / 2$ semaines avec des périodes de plantation suivant des intervalles de $1 / 2$ semaine. L'auteur passe en revue les facteurs de la survie et de la croissance après ces 20 années. Les résultats démontrent une diminution dans $10 \%$ de survie à mesure que la durée de l'entreposage augmentait. Simultanément, a-t-on noté une baisse de la surface terrière et du volume, malgré une augmentation partielle des diamètres lorsque le peuplement montre une plus faible densité. Après une semaine d'entreposage, la perte en volume se fixe à $12 \%$ après 20 ans. Les semis originant des cageots présentent une survie sulpérieure à ceux provenant des ballots $(+12 \%)$ et produisent $17 \%$ plus de volume ligneux après ces 20 années. Les différences obtenues relativement aux 2 équipes qui effectuèrent la plantation, différences peu décelables quelques années après la plantation, s'avèrent aujourd'sui significatives suivant le rapport des diamètres. Une des 2 équipes obtint ainsi une surface terrière et un volume supérieur de $14 \%$, à 20 ans, à la suite d'un travail plus efficace.

In 1953 an experiment was established to compare burlap bales with wooden crates for the shipping and holding of nursery stock under conditions in which planting might be delayed. Packing of seven bales and seven crates (1000 trees each) was done at Kemptville Nursery on 16 May 1953, using 2-2 red pine (Pinus resinosa Ait.). The trees were taken on the same day to Larose Forest, about 65 $\mathrm{km}$ east, and stored in a small shed. Starting on 18 May, planting was done at half-week intervals for seven times using one bale and one crate at each time. The establishment was done by two crews of two men, using the Wedge method in furrows, according to a randomized design of 140 plots.

Based on first-year data Mullin (1954) showed that survival decreased with length of storage (confounded with changes as the growing season advanced and/or decrease in the length of the growing season). Crates preserved the viability of the stock better than bales, and no differences were demonstrated between the two planting crews.

A study of survival and height at 5 years after planting confirmed the above (Leech 1959). Survival and height were both significantly reduced by delay in planting (or duration in holding), crates were still better than bales in survival but with no apparent differences in heights, and no differences were found between the planting crews.

At the 15th and 20th year, measurements were made of survival and diameter of all trees and data have been summarized in Table 1 .

\section{Results}

Decrease in survival with increase in length of holding has been highly significant from the begining, and is largely a linear relationship (Mullin 1954). Height was similar in its reaction at 5 years, but diameter at 15 and 20 years did not follow the same pattern; no significant correlation of diameter and time of planting was found (Table 1). There was a general pattern of larger trees at lower densities as discussed later.

The crate continued to hold, with high significance, an advantage over the bale in terms of survival. Height did not show a significant relationship at 5 years, nor did diameter at 15 years. However, at 20 years, the differences in diameter were significant at the $5.0 \%$ level, the inverse of the significant survival relationship.

Differences between the two planting crews were not significant in terms of survival at any time, nor in height at 5 years. However, differences in diameter were significant at 15 years $(5.0 \%$ level), and highly significant at 20 years $(1.0 \%$ level $)$.

\section{Practical considerations}

Holding nursery stock. The forest manager may be more interested in comparing the treatments through basal area (BA) of the stands, or volumes than through the bare statistics of survival, height or diameter. It could be expected that, as survival responded to a treatment, average diameter would respond in the opposite direction, as per yield tables 
(Stiell and Berry 1973) and SDI graphs (Husch 1963).

Therefore a further study of the effects of continued storage and later planting was made in terms of BA and volume per acre. Using survival and diameter data for the 140 plots at 20 years, the following expression of the relationship was obtained:

$$
\text { where } \begin{aligned}
& \mathrm{Y}=15.50-.031 \mathrm{X} \\
& \mathrm{Y}=\text { mean diameter in } \mathrm{cm} \\
& \mathrm{X}=\text { surival percentage }
\end{aligned}
$$

$\mathrm{t}$ for slope $=6.27$; significant at $0.1 \%$ level.

Also a linear expression of the time of planting or length of holding effect on survival at 20 years was obtained (Mullin 1954):

$$
\begin{aligned}
& \mathrm{Y}=82.75-4.127 \mathrm{X} \\
& \text { where } \mathrm{Y}=\text { survival percentage } \\
& \mathrm{X}=\text { time of planting, e.g. } 1 \text { to } 7 \text {. }
\end{aligned}
$$

Using these formulae, adjusted values of survival and diameter by time of planting were obtained, as shown in Table 2, and the BA calculated. The attendant volumes were obtained graphically by plotting volumes corresponding to BA for 6- $\times$ 6-ft plantings from the yield tables of Stiell and Berry (1973). The decline in the quantity of the stand occurred even though all were on the same site, simply through the lasting effect of the survival differences from delayed planting or longer storage. For one week of holding, under these conditions of unrefrigerated storage, a drop in volume of over $12 \%$ at 20 years could be expected. This is an obvious warning of the dangers of any unnecessary holding of trees.
Bales versus crates. As shown in Table 1, both survival rate and diameter are significantly different at 20 years, for the main effects due to bales and crates. The spread in difference in survival rate has grown from about $7.13 \%$ at one year, to $11.50 \%$ at 20 years. The differences in diameter at 20 years, between bales and crates, can be considered almost entirely due to the differences in survival or density, because the actual diameters for bales and crates, $13.50 \mathrm{~cm}$ and $13.32 \mathrm{~cm}$ respectively, were so similar to the calculated diameters (from $Y=$ $15.5-.031 \mathrm{X}$ ) of 13.56 and $13.34 \mathrm{~cm}$ respectively.

From measured survival and diameter data the BA was obtained as shown in Table 2 and volumes calculated. These show a difference of almost $17 \%$ better volume for crates than for bales. Such differences may well cast doubt on the continued use of the standard burlap bales, in line with the recommendations of Ursic (1963).

Planting crews: Finally, there was an interesting difference between the two planting crews, $X$ and $Y$ (Tables 1 and 2 ). No significant differences in survival were found throughout the experiment, and no significant difference in height at 5 years. However, at the 15th and 20th years, the differences in average diameter were significant at the $5.0 \%$ and $1.0 \%$ levels respectively.

Using the average survival rate of the experiment $(66.25 \%)$ for both crews (as crews were not significantly different) and the significantly different diameters, the BA was calculated as in Table 2. Corresponding volumes were obtained as before. This comparison shows that the planting crews had a large effect on volume at 20 years, crew $X$ producing about $14 \%$ greater volume than crew $Y$.

TABLE 1. Survival, height and diameter averages by treatments; to 20 years after planting

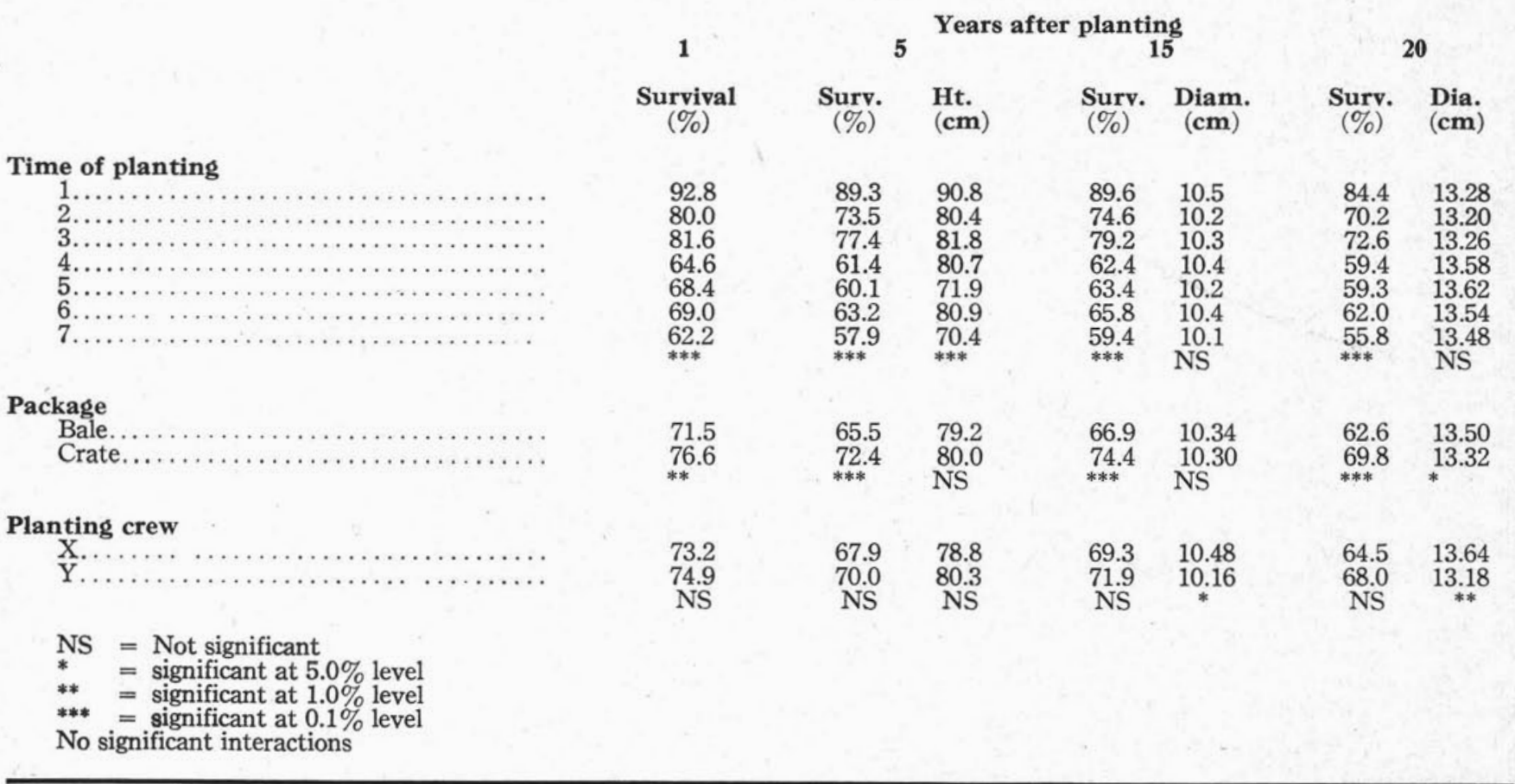


TABLE 2. Survival and diameter at 20 years with basal area and volume approximations

$\frac{\text { Survival }}{\underset{\%}{\text { Actual }} \underset{\%}{\text { Adjusteda }}}$

Time of planting

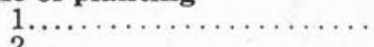

$2 \ldots \ldots+\cdots \ldots \ldots \ldots$

$3 \ldots \ldots \ldots \ldots \ldots \ldots \ldots$

$4 \ldots \ldots \ldots \ldots \ldots \ldots \ldots \ldots$

$5 \ldots \ldots \ldots \ldots \ldots \ldots$

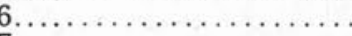

$7 \ldots \ldots \ldots \ldots \ldots \ldots \ldots \ldots$

Packaged

Bale................ 62.6

Crate.............

Planting crew

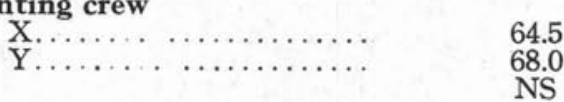

64.5
68.0
NS

\section{Diameter \\ Adjusted $^{\mathrm{b}}$ \\ cm}

$\begin{array}{ll}84.4 & 78.6 \\ 70.2 & 74.5 \\ 72.6 & 70.4 \\ 59.4 & 66.2 \\ 59.3 & 62.1 \\ 62.0 & 58.0 \\ 55.8 & 53.9 \\ * * * & \end{array}$

3.9
13.06

13.19

13.32

13.45

13.57

13.70

13.83

13.50

13.32

13.64

13.18
BA/acre

12.74

12.32

11.87

11.38

10.87

10.34

9.80

10.86

11.77

11.71

10.94
Vol/acre

$\mathbf{m}^{3}$

64.00

60.31

56.07

52.10

47.57

42.76

37.94

47.57

55.50

54.93

48.14
Vol/acre $\mathrm{ft}^{3}$

\section{0}

2130

1980

1840

1680

1510

1340

1680

1960

1940

1700

a $\quad=$ From $\mathrm{Y}=82.75-4.127 \mathrm{X}$, for Surival by Time $(1$ to 7$)$

b $\quad=$ From $\mathrm{Y}=15.50-.031 \mathrm{X}$, for Diameter by Survival $(\%)$

$\mathrm{NS}=$ Not significant

* $\quad=$ significant at $5.0 \%$ level

** $\quad=$ significant at $1.0 \%$ level

*** $=$ significant at $0.1 \%$ level

No significant interactions

Crew $X$ by better planting, or a "green thumb" effect, obtained an importantly larger stand volume at 20 years than did crew $Y$. This is an obvious corroboration of the need for good planting, and the need to control crew differences in planting experiments.

\section{References}

HUSCH, 1963. Forest mensuration and statistics. Ronald Press Co., New York. 474 p.
LEECH, R. H. 1959. A second look at a nursery stock packaging experiment. Forest. Chron. 35: 36-49.

MULLIN, R. E. 1954. Nursery stock packaging experiment. Ont. Dep. Lands Forests, Res. Br., Res. Rep. 27. 16 p.

STIELL, W. M. and A. B. BERRY. 1973. Yield of unthinned red pine plantations at the Petawawa Forest Experiment Station. Environ. Can. Forest. Serv., Publ. 1320. 16 p.

URSIC, S. J. 1963. Kraft-polyethylene bags recommended for packing and storing loblolly seedlings. US Forest Serv. T.P.N. 57: 23-28.
TEL.: 819 - 326-3559

TIMMERLINN

WILLIAM S. POLLOCK CONSULTING FOREST ENGINEER

TIMMERLINN WOODLAND SERVICES, R. R. No. 2, - STE. AGATHE DES MONTS, QUE.



Industrial Forestry Service Ltd.

CONSULTING

FORESTERS

ENGINEERS
101-1595 FIFTH AVE., PRINCE GEORGE, B.C.

TEL.: 563-9207 